\title{
Distribution of Corticosteroid Receptors in the Rhesus Brain: Relative Absence of Glucocorticoid Receptors in the Hippocampal Formation
}

\author{
M. Mar Sánchez, ${ }^{1,2}$ Larry J. Young, ${ }^{1}$ Paul M. Plotsky, ${ }^{1}$ and Thomas R. Insel ${ }^{1,2}$ \\ ${ }^{1}$ Department of Psychiatry and Behavioral Sciences, and ${ }^{2}$ Yerkes Regional Primate Research Center, Emory University, \\ Atlanta, Georgia 30322
}

\begin{abstract}
Chronic stress has been associated with degenerative changes in the rodent and primate hippocampus, presumably mediated in part via neuronal glucocorticoid receptors (GRs). In the rat brain, GRs are widely distributed and are particularly dense in the hippocampus. The distribution of GRs in the primate brain, however, has not been fully characterized. In this study, we used in situ hybridization histochemistry and immunohistochemistry to map the distribution of GR mRNA and GR protein, respectively, in adult rhesus monkeys (Macaca mulatta). In contrast to its well established distribution in the rat brain, GR mRNA was only weakly detected in the dentate gyrus (DG) and Cornu Ammonis (CA) of the macaque hippocampus, whereas it was abundant in the pituitary (PIT), cerebellum (CBL), hypothalamic paraventricular nucleus (PVN), and, to a lesser extent, the neocortex. Immunohistochemical staining indicated a very low
\end{abstract}

density of GR-like immunoreactive cells within the macaque hippocampal formation in contrast to the high density observed within the PVN, prefrontal and entorhinal cortices, and cerebellar cortex. Relative to the low level of GR, mineralocorticoid receptor (MR) mRNA and protein expression were abundant within the DG and CA of the rhesus monkey hippocampal formation. These results indicate that, in the primate, neocortical and hypothalamic areas may be more important targets for GR-mediated effects of glucocorticoids than the hippocampus. Alternatively, it is also possible that glucocorticoid effects are mediated through the MRs present in the hippocampal formation.

Key words: hippocampus; glucocorticoid receptor; mineralocorticoid receptor; rhesus monkey; immunohistochemistry; in situ hybridization
Hypothalamic-pituitary-adrenal (HPA) axis function is regulated via the negative feedback actions of glucocorticoids (GCs) at the level of the pituitary, hypothalamus, and suprahypothalamic limbic structures such as the hippocampus and amygdala. Feedback is mediated by the action of GC at two types of adrenal steroid receptors, the type I or mineralocorticoid receptor (MR) and the type II or glucocorticoid receptor (GR). Both types of receptors have been extensively studied in the CNS of the rat, dog, mouse, and hamster (Coirini et al., 1985; Reul and de Kloet, 1985; Luttge and Rupp, 1989; Reul et al., 1990). The GR has a high affinity for synthetic glucocorticoid analogs such as dexamethasone and RU28362, with a lower affinity for corticosterone and cortisol (Reul and de Kloet, 1985). In the rodent brain, the GRs are widely distributed and are particularly dense in the hippocampus and hypothalamic paraventricular nucleus (PVN) (Fuxe et al., 1985; Reul and de Kloet, 1985; Uht et al., 1988; Van Eekelen et al., 1988; Sousa et al., 1989; Jacobson and Sapolsky, 1991). In contrast, the MRs bind corticosterone (or cortisol) and aldosterone with high affinity and are primarily localized in the hippocampus and septum (Veldhuis et al., 1982; Reul and de

Received Dec. 20, 1999; revised March 21, 2000; accepted April 4, 2000.

This work was supported by the Yerkes Regional Primate Research Center base Grant RR-00165 (Comparative Medicine Program, National Center for Research Resources of the National Institutes of Health), Grant MH58922 (P.M.P.), and the Klingenstein Third Generation Foundation Fellowship in Childhood and Adolescent Depression (M.M.S.). We thank Drs. Y. Smith, A. Miller, and B. Pearce for their help and suggestions during this study.

Correspondence should be addressed to Dr. M. Mar Sánchez, Department of Psychiatry and Behavioral Sciences, Emory University School of Medicine, 1639 Pierce Drive, Atlanta, GA 30322. E-mail: sanchez@rmy.emory.edu.

Copyright $\odot 2000$ Society for Neuroscience $0270-6474 / 00 / 204657-12 \$ 15.00 / 0$
Kloet, 1985; McEwen et al., 1986; Jacobson and Sapolsky, 1991). Available evidence from rat studies suggests that hippocampal GRs participate in the shut-off of the HPA axis activation aimed at restoring homeostasis, whereas MRs are involved in regulating basal or trough levels of glucocorticoids (McEwen et al., 1986; de Kloet et al., 1987; Jacobson and Sapolsky, 1991).

In the past decade a growing literature has described degenerative changes in the hippocampus as a result of chronic stress (Sapolsky et al., 1986; Bremner, 1999). These reports, which were originally based on studies of rat brain and later extended to monkey and human brain, consistently conclude that stressrelated hippocampal damage is mediated by high levels of glucocorticoids acting on hippocampal GRs. Whereas the anatomic distribution of rat hippocampal GR has been extensively described, surprisingly little is known about either GR or MR distribution in the primate brain. The cDNAs for human GR and MR have been cloned, and each corticosteroid receptor exists in two isoforms (Hollenberg et al., 1985; Arriza et al., 1987; Zennaro et al., 1995), allowing their structural and functional characterization (Alnemri et al., 1991; Rupprecht et al., 1993). There are, however, few quantitative or comprehensive analyses of receptor binding available in primate brain (Tsuboi et al., 1979; Yu et al., 1981; Sapolsky and Meaney, 1988; Brooke et al., 1994b), partially because of the difficulty of obtaining tissue from adrenalectomized animals. Indeed, to our knowledge, there are no detailed studies of regional expression of these receptors or their mRNAs in the primate brain. In this study, we have mapped both GR and MR mRNA as well as protein distribution in the macaque CNS and pituitary using in situ hybridization histochemistry and immunohistochemistry, respectively. Our results suggest 
that extrapolation from rat brain to primate brain may be misleading.

\section{MATERIALS AND METHODS}

Subjects and tissue collection. The brains and pituitaries used for analysis in this study were obtained from eight adult rhesus monkeys. Two males and two females, ages 5-13 years, were used for the in situ hybridization study. The immunocytochemical study of GR and MR was performed in tissue obtained from two males and two females ranging in age from 4 to 19 years old. After sedation with ketamine hydrochloride $(10 \mathrm{mg} / \mathrm{kg}$ body weight, i.m.) all animals were killed with an overdose of sodium pentobarbital according to procedures recommended by the Panel on Euthanasia of the American Veterinary Medical Association. For in situ hybridization, the brains and pituitaries were quickly removed, and the latter were frozen on dry ice. After a wash with cold PBS, brains were cut into $1 \mathrm{~cm}$ coronal blocks using a rhesus brain matrix (A.S.I. Instruments, Warren, MA). The brain blocks were then rapidly frozen on an aluminum plate on dry ice and stored at $-70^{\circ} \mathrm{C}$ until further analysis. For immunocytochemistry, three of the animals were perfusion-fixed under deep anesthesia using cold Ringer's solution followed by fixative containing $4 \%$ paraformaldehyde and $0.1 \%$ glutaraldehyde in sodium phosphate buffer (PB; $0.1 \mathrm{M}, \mathrm{pH} 7.4)$. The fourth subject was perfusion-fixed with $2 \%$ paraformaldehyde, $0.05 \%$ glutaraldehyde, and $0.2 \%$ picric acid to compare the effects of different fixatives on the antigenicity of the epitopes recognized by the antibodies. Coronal sections (60- $\mu$ m-thick) were obtained from the perfusion-fixed monkey brains on a vibrating microtome.

Brain sections from adult Sprague Dawley rats (Harlan) were also obtained to compare results with those from the primate brain. For in situ hybridization, animals were anesthetized, and the brains were rapidly removed, frozen on dry ice, and stored at $-70^{\circ} \mathrm{C}$ until further analysis. For immunocytochemical studies, the animals were perfused either with a cold Ringer's solution followed by fixative containing $4 \%$ paraformaldehyde and $0.1 \%$ glutaraldehyde in PB or with cold $0.9 \%$ saline followed by a cold fixative solution containing $4 \%$ paraformaldehyde in PB. The brains were then removed and, for the former fixative, coronal sections $(60-\mu \mathrm{m}$-thick) were obtained on a vibrating microtome. For the latter fixative, the brains were post-fixed for $3 \mathrm{hr}$ in $4 \%$ paraformaldehyde in $\mathrm{PB}$ and then immersed in $0.1 \mathrm{M} \mathrm{PB}$ containing $20 \%$ sucrose for $48 \mathrm{hr}$ at $4^{\circ} \mathrm{C}$. The tissue was then frozen on dry ice, and $30-\mu \mathrm{m}$-thick coronal sections were cut on a cryostat.

In situ hybridization. Serial $20 \mu \mathrm{m}$ sections from the fresh frozen rhesus tissue blocks and rat brains were collected via cryostat sectioning. The sections were thaw-mounted onto glass slides precoated with gelatin and poly-L-lysine or on Superfrost Plus slides $(3 \times 1$ inch; Fisher Scientific, Santa Clara, CA; $3 \times 1.5$ inch; Brain Research Laboratories, Waban, MA), vacuum-dried overnight at $4^{\circ} \mathrm{C}$, and then stored at $-70^{\circ} \mathrm{C}$ in airtight containers with desiccant.

In adjacent sections, radiolabeled human cRNA probes were used to detect glucocorticoid (type II or GR) or mineralocorticoid (type I or MR) receptor mRNAs by means of in situ hybridization following procedures described previously (Young et al., 1997; Sánchez et al., 1999). Frozen sections were thawed and fixed in $4 \%$ paraformaldehyde ( $\mathrm{pH} 7.4,20 \mathrm{~min}$ at room temperature), rinsed twice for $5 \mathrm{~min}$ in $1 \times$ PBS followed by a $15 \mathrm{~min}$ proteinase $\mathrm{K}$ digestion $(10 \mu \mathrm{g} / \mathrm{ml}$ in $50 \mathrm{~mm}$ Tris- $\mathrm{HCl}, \mathrm{pH} 8.0,5 \mathrm{~mm}$ EDTA) at room temperature. After a rinse in deionized water, the sections were acetylated for $10 \mathrm{~min}$ in freshly prepared $0.25 \%$ acetic anhydride in $0.1 \mathrm{M}$ triethanolamine (TEA; $\mathrm{pH}$ 8.0 ), rinsed in $2 \times$ SSC, dehydrated in ascending ethanols, delipidated in chloroform, rinsed in $95 \%$ ethanol, and air-dried. Sections were then prehybridized for $2 \mathrm{hr}$ at $53^{\circ} \mathrm{C}$, rinsed in $2 \times \mathrm{SSC}$, dehydrated in ascending ethanols, and air-dried before hybridization. For studies of GR mRNA, $\left[{ }^{35} \mathrm{~S}\right]$-radiolabeled antisense and sense cRNAs were transcribed from a 472 bp cDNA EcoRI-XbaI fragment subcloned from a $4.79 \mathrm{~kb}$ human GR cDNA clone (pOB7; Hollenberg et al., 1985) kindly provided by Dr. R. M. Evans (The Salk Institute, La Jolla, CA). This 472 bp cDNA clone spans nucleotides $2347-2846$ of the $\alpha$ mRNA sequence of the human GR, corresponding to 3' translated and nontranslated regions and does not share sequence homology with the $\beta$ mRNA isoform. This nucleotide sequence of the human GR is highly conserved among species, sharing a $95 \%$ homology with GRs of other primates and $93 \%$ homology with the rat GR. To analyze MR mRNA, radiolabeled antisense and sense strand RNA probes were transcribed from a $298 \mathrm{bp}$ cDNA clone amplified from a $3.75 \mathrm{~kb}$ cDNA clone encoding the human MR (Arriza et al., 1987; kindly provided by Dr. R. M. Evans), using custom-designed primers and following the PCR method. This 298 bp PCR product was subcloned into the pCRII-TOPO vector (Invitrogen, Carlsbad, CA) and corresponds to nucleotides 1515-1812 of the human MR coding region, therefore recognizing both $\alpha$ and $\beta$ MR mRNA isoforms. The GR and MR probes did not cross-react because of the lack of homology between nucleotide sequences of the two cDNAs. Antisense and sense cRNA probes were synthesized incorporating $\left[{ }^{35} \mathrm{~S}\right]-\mathrm{CTP}$ (New England Nuclear, Boston, MA) at a specific activity of $9 \times 10^{8} \mathrm{cpm} / \mu \mathrm{g}$ probe. Purified cRNA probes were heat-denatured and added to the hybridization solution at a final concentration of $0.3 \mu \mathrm{g}$ probe $\times$ length (in kilobases) per milliliter. Hybridization solution was applied to the sections $(150 \mu \mathrm{l}$ to $3 \times 1$ inch slides or $210 \mu \mathrm{l}$ to $3 \times 1.5$ inch slides $)$ and, after an overnight hybridization at $53^{\circ} \mathrm{C}$, the sections were washed twice for $15 \mathrm{~min}$ each in $2 \times \mathrm{SSC}, 50 \%$ formamide, $0.1 \% 2-\beta$-mercaptoethanol $\left(2-\mathrm{ME}\right.$ ) at $53^{\circ} \mathrm{C}$, then treated with ribonuclease A (RNase; $20 \mu \mathrm{g} / \mathrm{ml}$ in RNase buffer) for $30 \mathrm{~min}$ at $37^{\circ} \mathrm{C}$ followed by incubation with DTT (1 $\mathrm{mm}$ ) in RNase buffer for $30 \mathrm{~min}$ at $37^{\circ} \mathrm{C}$. Thereafter, sections were washed twice for $15 \mathrm{~min}$ each in $2 \times \mathrm{SSC}$ and $0.1 \% 2-\mathrm{ME}$ at $53^{\circ} \mathrm{C}$. Final high-stringency washes consisted of two $30 \mathrm{~min}$ washes in $0.1 \times$ SSC and $1 \% 2-\mathrm{ME}$ at $53^{\circ} \mathrm{C}$. The sections were then dehydrated in alcohol, airdried, and exposed to Kodak (Eastman Kodak, Rochester, NY) BioMax MR film along with autoradiographic $\left[{ }^{14} \mathrm{C}\right]$ microscale standards (Amersham, Arlington Heights, IL) for 10-15 d at room temperature. Specific mRNA hybridization was determined by comparing the hybridization signal from the antisense with that of the sense cRNA strand probe (see Figs. 1, 2, 7 and 8). Representative sections were then dipped in NTB2 nuclear emulsion (Eastman Kodak), exposed for 3-8 weeks, developed, and counterstained using thionin for microscopic examination of neuroanatomical localization of the receptor mRNAs.

Immunocytochemistry. The sections from the perfusion-fixed monkey and rat brains were processed for the immunohistochemical localization of GR and MR proteins at the light-microscope level. The sections were pretreated with sodium borohydride (1\% in PBS, $0.01 \mathrm{M}, \mathrm{pH} 7.4$ ) for 20 min and with $20 \%$ methanol and $0.3 \% \mathrm{H}_{2} \mathrm{O}_{2}$ in PBS for 30 min. They were preincubated with either $10 \%$ normal goat serum (NGS; Vector Laboratories, Burlingame, CA) for GR immunostaining or normal donkey serum (NDS; Jackson ImmunoResearch, West Grove, PA) for MR immunostaining, $1 \%$ bovine serum albumin (BSA; Sigma, St. Louis, $\mathrm{MO}$ ) and $0.4 \%$ Triton X-100 in PBS for $2 \mathrm{hr}$ at room temperature. The sections were then incubated at $4^{\circ} \mathrm{C}$ for $48 \mathrm{hr}$ in the GR or MR primary antibody solutions using either of two polyclonal (rabbit) anti-human GR antibodies [GR 57; 1:2000; Affinity Bioreagents; or GR (E-20); 1:1000; Santa Cruz Biotechnology, Santa Cruz, CA] or a polyclonal (goat) anti-human MR antibody [MCR (N-17); 1:1000; Santa Cruz Biotechnology), in PBS and $1 \%$ NGS (or NDS) and 1\%BSA with $0.4 \%$ Triton $\mathrm{X}-100$. The two GR antibodies used react with both the $\alpha$ and $\beta$ GR isoforms. The sections were then incubated with biotinylated anti-rabbit IgGs (1:200; Vector Laboratories) for $2 \mathrm{hr}$ at room temperature and then placed in avidin-biotin-peroxidase (ABC) complex (1:100; Vector Laboratories) for $1.5 \mathrm{hr}$. Tissue was developed in chromagen solution by using a $0.03 \% 3-3^{\prime}$ diaminobenzidine- $4 \mathrm{HCl}(\mathrm{DAB})$ solution, containing $0.003 \% \mathrm{H}_{2} \mathrm{O}_{2}$ and $0.1 \mathrm{M}$ nickel sulfate in acetate-imidazole buffer (125 mM sodium acetate and $10 \mathrm{~mm}$ imidazole, $\mathrm{pH}$ 6.5) for 7-10 min at room temperature. The specificity of immunostaining was established by comparing adjacent tissue sections that where incubated either with the absorbed immunosera (i.e., GR57, E-20, or MCR antisera that had been previously incubated overnight with a fivefold excess of their respective peptide immunogens at $4^{\circ} \mathrm{C}$ ) or without the inclusion of primary antiserum.

An additional immunocytochemical study was performed on adjacent sections to those used for in situ hybridization analysis to analyze the effects of the fixatives and antibody penetration on the GR immunoreactivity obtained. Frozen sections $(20-\mu \mathrm{m}$-thick) were thawed and fixed in prechilled $95 \% \mathrm{EtOH}$ for $10 \mathrm{~min}$. After a $5 \mathrm{~min}$ wash in $\mathrm{PBS}$ at $4^{\circ} \mathrm{C}$, sections were incubated with an endogenous peroxidase blocking agent (Dako, Carpinteria, CA) for $10 \mathrm{~min}$, followed by pretreatment with an avidin-biotin blocking kit (Vector Laboratories, Burlingame, CA) and preincubation with $10 \%$ NGS and $0.2 \%$ BSA in PBS for 15 min at room temperature. The sections were then incubated in the GR57 antibody solution (1:1500) in PBS plus $1 \%$ NGS and $0.2 \%$ BSA at $4^{\circ} \mathrm{C}$ for $24 \mathrm{hr}$ followed by incubation with biotinylated anti-rabbit IgGs (1:200; in PBS plus $1 \%$ NGS and $0.2 \%$ BSA) for $1.5 \mathrm{hr}$ at room temperature. Sections were then placed in $\mathrm{ABC}$ solution (1:100) for $45 \mathrm{~min}$, developed with a $0.04 \%$ DAB solution, containing $0.01 \% \mathrm{H}_{2} \mathrm{O}_{2}$ in Tris-imidazole buffer (50 mM Tris and $10 \mathrm{~mm}$ imidazole, $\mathrm{pH}$ 7.2) for $30 \mathrm{~min}$ at room temper- 
ature and lightly counterstained with thionin. The specificity of immunostaining was established by comparing adjacent tissue sections that where incubated with the absorbed immunosera.

To determine if GR-like-immunoreactive profiles belonged to neurons or glial cells, we double-labeled some sections with GR and either microtubule-associated protein-2 (MAP-2) or glial fibrillary acidic protein (GFAP). After staining for GR, as described above, sections were preincubated with $10 \%$ normal horse serum (NHS; Sigma) with $1 \%$ BSA and $0.4 \%$ Triton $\mathrm{X}-100$ in PBS for $2 \mathrm{hr}$ at room temperature, followed by incubation with either a monoclonal (mouse) anti-MAP-2 (1:1000; Boehringer Mannheim, Indianapolis, IN) or anti-GFAP (1:1000; Sigma) antibody in PBS with $1 \%$ NHS, $1 \%$ BSA, and $0.4 \%$ Triton X-100. The sections were then incubated with biotinylated horse anti-mouse IgGs (1:500; Vector Laboratories) for $1.5 \mathrm{hr}$ at room temperature and placed in ABC complex (1:100; Vector Laboratories) for $1.5 \mathrm{hr}$. Tissue was developed in chromagen solution by using a $0.04 \% 3-3$ 'diaminobenzidine$4 \mathrm{HCl}(\mathrm{DAB})$ solution, containing $0.003 \% \mathrm{H}_{2} \mathrm{O}_{2}$ in Tris-imidazole buffer for $7 \mathrm{~min}$.

Data analysis. Autoradiograms from in situ hybridization studies were analyzed using the NIH Image program (http://rsb.info.gov/nih-image). The mean optical density (OD) per area was measured in each area of interest [i.e., pituitary, hippocampal formation-including DG, hippocampus proper (Cornu Ammonis subfields CA1-CA4)—hypothalamic PVN, prefrontal, parietal, entorhinal/perirhinal and temporal cortices, and cerebellar cortex] for both the antisense (AS) and sense (S) strand radiolabeled cRNA probes. Specific mRNA hybridization signal was calculated by subtracting the S from the total AS mean optical density obtained in each area of interest. An average of three to four matched sections were analyzed per region in a total of four animals (two males and two females) for each region to generate mean OD units values.

Captured images were not altered, except for contrast enhancement for illustration purposes and were printed using Adobe Photoshop software (Adobe Systems, Mountain View, CA), except for Figures 3, 4B-E, $5,6 B, C, 9 B-E$, and $10 B$, which are direct light photomicrographs.

Neuroanatomical localization of structures in both in situ hybridization and immunocytochemistry studies was based on several macaque brain atlases (Snider and Lee, 1961; Martin and Bowden, 1997; Paxinos et al., 2000) and specific neuroanatomic reviews (Rosene and Van Hoesen, 1987).

\section{RESULTS}

There were no apparent age- or gender-related differences in the pattern of GR mRNA hybridization signal or GR-like immunoreactivity across the animals used for these studies. The levels of sense cRNA hybridization and immunostaining obtained with the preabsorbed antibodies were consistently low across sections except in the case of the GR hybridization signal in the hippocampal formation (see below).

\section{GR in situ hybridization}

A very intense GR mRNA hybridization signal was found in several regions, including the anterior lobe of the pituitary (AL), molecular layer of the cerebellar cortex (ML) and PVN, as shown in Figure 1 and quantified in Table 1. Moderate to high levels of GR mRNA were found in neocortical/allocortical areas with particularly high signal in temporal/entorhinal, parietal, cingulate, and prefrontal cortices. Surprisingly, low levels of GR mRNA were found within the hippocampal formation, although some signal was evident within apparent neuronal elements of the DG. The hybridization signal detected in the Cornu Ammonis and DG using the radiolabeled human cRNA antisense probe was similar in density to that shown using the sense probe (Fig. 1) and, therefore, likely represented nonspecific hybridization. This high level of nonspecific hybridization in the hippocampus stands in contrast to other regions studied where the sense strand produced a uniform, low background level of hybridization and was in sharp contrast to the high levels of specific GR mRNA signal found in the rat hippocampus (Fig. 2; Sousa et al., 1989; Morimoto et al., 1996).

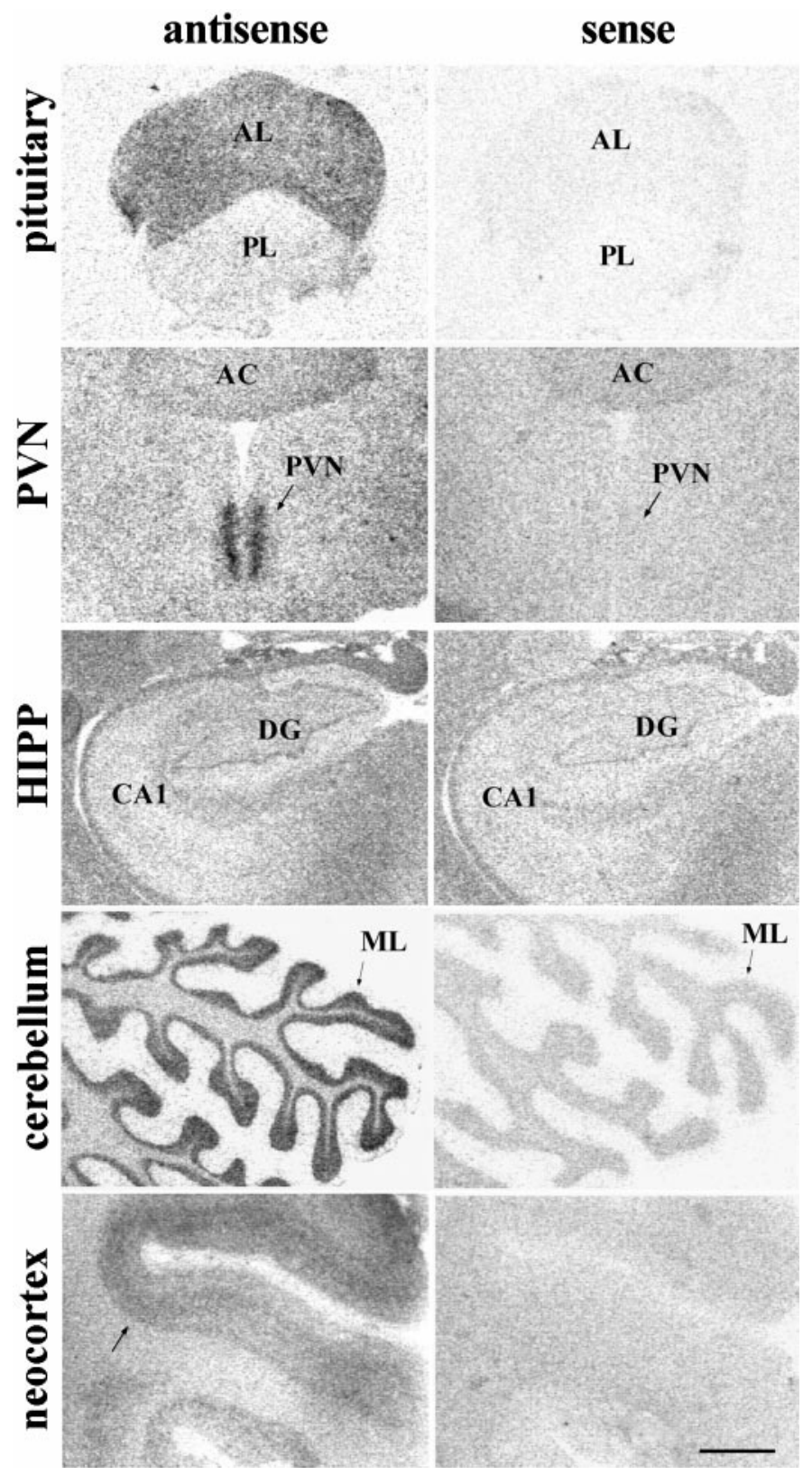

Figure 1. Left, Representative autoradiograms showing GR mRNA in situ hybridization signal with the $\left[{ }^{35} \mathrm{~S}\right]$-labeled human cRNA antisense probe in the rhesus macaque pituitary and several regions of the CNS. Note the low hybridization levels obtained in DG and CA1-4 of the hippocampal formation, in comparison to the other regions sampled. Right, Hybridization signal detected when using the sense cRNA radiolabeled probe in adjacent sections. Scale bar, $1.5 \mathrm{~mm}$. $A C$, Anterior commissure; $A L$, anterior lobe of the pituitary; $B N S T$, bed nucleus of the stria terminalis; $C A 1-4$, Cornu Ammonis subfields (1-4); $C B L$, cerebellum; $C E A$, central nucleus of amygdala; $D G$, dentate gyrus of the hippocampus; Ent ctx, Entorhinal cortex; GL, cerebellar cortex, granular layer; HIPP, hippocampal formation; $M L$, cerebellar cortex, molecular layer; $M E A$, medial nucleus of amygdala; $P$, cerebellar cortex, Purkinje cell layer; $P I T$, pituitary; $P L$, posterior lobe of the pituitary; PreS, presubiculum; ProS, prosubiculum; $P V N$, hypothalamic paraventricular nucleus; $S O N$, supraoptic nucleus; Sub, subiculum; $V M H$, ventromedial hypothalamic nucleus; $V$, third ventricle. 


\begin{tabular}{|c|c|}
\hline Region & $(\mathrm{OD})$ Mean $\pm \mathrm{SEM}$ \\
\hline PIT & $57.00 \pm 7.15$ \\
\hline CBL & $44.22 \pm 5.01$ \\
\hline PVN & $27.39 \pm 5.76$ \\
\hline Neocortex & $20.99 \pm 5.07$ \\
\hline DG & $12.70 \pm 2.72$ \\
\hline CA1 & $13.62 \pm 4.85$ \\
\hline $\mathrm{CA} 2$ & $11.44 \pm 0.00$ \\
\hline CA3 & $6.15 \pm 2.11$ \\
\hline
\end{tabular}

Data represent specific mean gray levels obtained by subtraction of the OD units generated with the sense radiolabeled cRNA from those obtained with the antisense probe in adjacent sections and after background subtraction. Mean gray levels expressed as optical (OD) units. Results derived from in situ hybridization histochemistry; three or four sections quantified per animal; $n=4$ animals, (two males and two females).
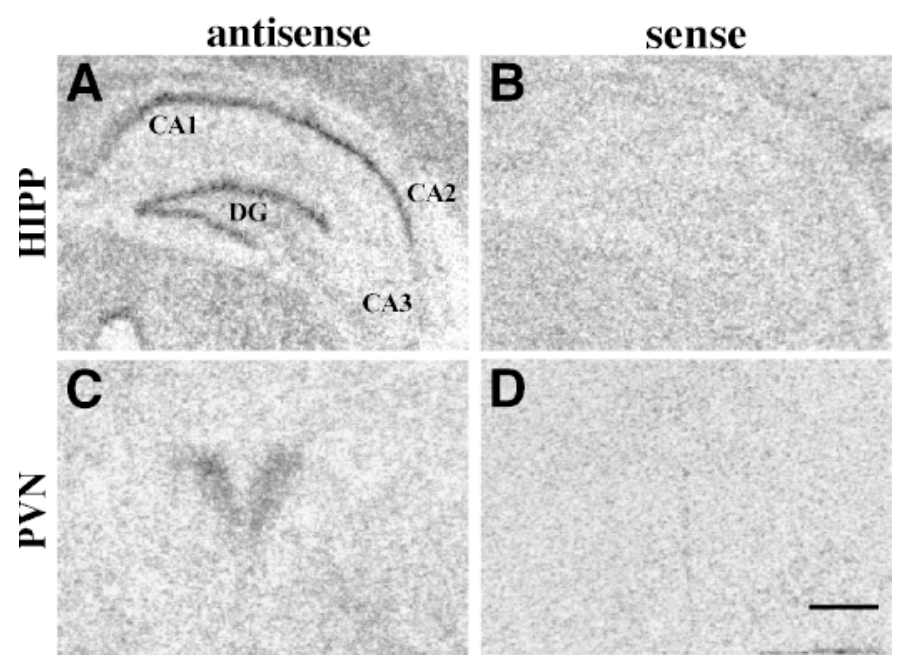

Figure 2. $A, C$, GR mRNA in situ hybridization signal within the rat paraventricular nucleus $(P V N)$ and hippocampal formation $(H I P P)$. Note the high levels of GR mRNA detected in both rat regions; $B, D$, hybridization signal detected when using the sense cRNA radiolabeled probe in adjacent sections. Scale bar, $0.5 \mathrm{~mm}$.

\section{GR immunocytochemistry}

Both GR antisera used in this study (GR57 or E-20) as well as the different fixative techniques (paraformaldehyde-glutaraldehyde and paraformaldehyde-picric acid-glutaraldehyde fixativeperfused sections, snap-frozen sections fixed with ethanol) yielded similar results. Neither the preabsorbed GR (GR57 and E-20) or MR antisera (MCR) used in this study showed specific immunoreactivity in monkey or rat tissue.

As shown in Figure 3, GR-IR cells were detected within the same regions of the rhesus monkey brain that expressed GR mRNA, including the PVN, prefrontal and entorhinal cortices, as well as the cerebellar cortex. The strongest immunostaining was observed in the PVN (Fig. 3A,B). Within neocortical areas and the entorhinal cortex, GR-IR cells were particularly dense in layers II and III, whereas a more moderate density of immunoreactive processes were visible in layers IV-VI, and layer I was almost devoid of GR-IR cells (Fig. 3E,F). Intense nuclear immunoreactivity predominated, although weak cytoplasmic staining was also detected in scattered cells throughout these areas. The cell nucleolus did not exhibit immunoreactivity. In some cases,
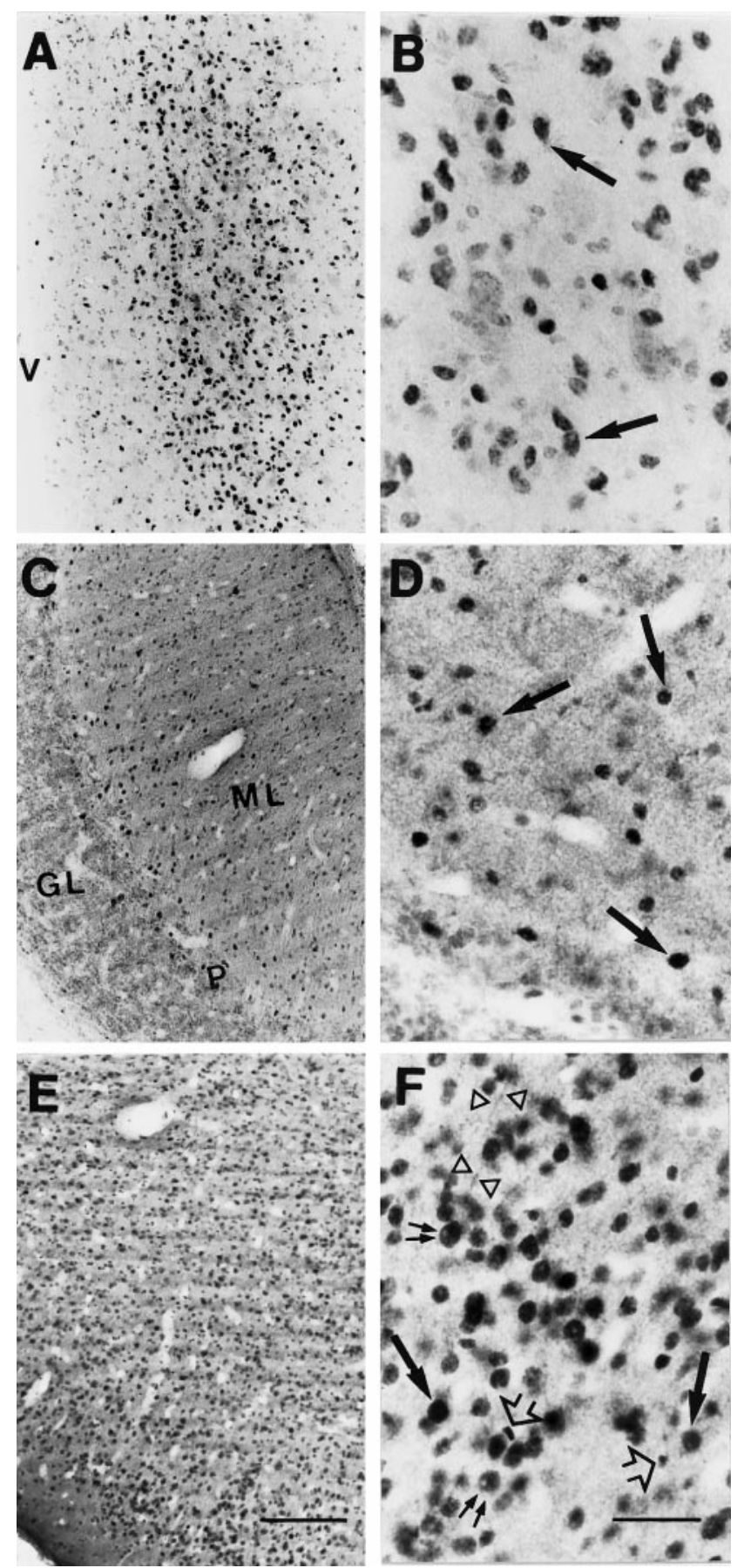

Figure 3. Light micrographs $(A, C, E, 10 \times ; B, D, F, 40 \times)$ showing the immunohistochemical localization of GR in coronal sections through sampled regions of the rhesus monkey CNS. $A, B$, High density of strongly immunoreactive neuronal nuclei in the PVN; $C, D$, section through the cerebellar cortex showing clusters of intensely immunostained nuclei (arrows) in the molecular cell layer $(M L)$, very close to the Purkinje cell layer $(P)$, and low density of moderately GR-IR cells in the rest of ML; very few GR-IR processes are detected in the granule cell layer $(G L) ; E$, $F$, the entorhinal cortex (but also neocortical areas, such as the prefrontal cortex) shows high densities of intensely GR-IR cells in layers II-V I. Note the predominant and intense nuclear immunoreactivity (arrows) in all these regions. The big nuclear profile size of most of the GR-IR cells seem to belong to neurons (arrows), except for a few scattered small GR-IR nuclei (arrowheads), which could belong to glial cells. The cell nucleolus does not exhibit immunoreactivity (double arrow), and some GR-IR neurites were detected (open triangles). Scale bars: E, $150 \mu \mathrm{m}$ $(10 \times) ; F, 50 \mu \mathrm{m}(40 \times)$. 

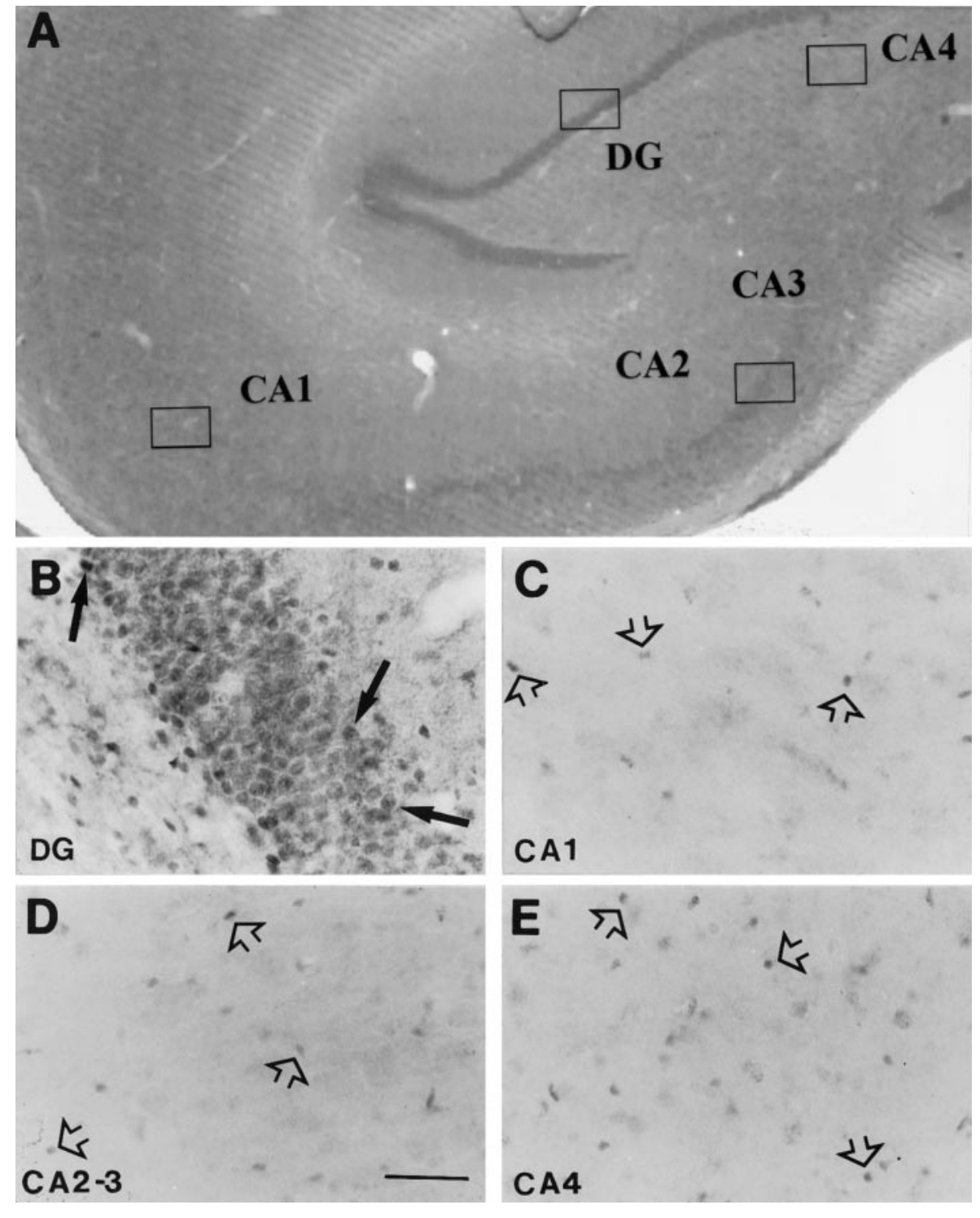

Figure 4. Photomicrographs of coronal sections through the macaque hippocampal formation, where a very low density of moderately GR-IR cells was observed. $A$, Low magnification view of the primate hippocampus; $B$, granule cells in the DG, where some moderately stained GR-IR nuclei were found (arrows); representative images of CA1 $(C)$, CA2-3 $(D)$, and CA4 $(E)$ subfields, showing a very low density of very lightly stained GR-immunoreactive nuclei whose predominant small nuclear profile size could belong to glial cells (arrowheads). Scale bar (applies to $B-E$ ), 50 $\mu \mathrm{m} ; 40 \times$.
GR-immunoreactivity was observed in the proximity of neurites, most likely apical dendrites of pyramidal neurons within the prefrontal and entorhinal cortices (Fig. $3 F$, open triangles). Coronal sections through the macaque cerebellar cortex showed clusters of intensely immunostained nuclei in the molecular cell layer $(\mathrm{ML})$ in the vicinity of the Purkinje cell layer (Fig. 3C,D) and, occasionally, in the Purkinje cell layer itself. A low density of moderately GR-positive nuclei were present in the rest of the molecular cell layer with very few immunoreactive cells detected in the granule cell layer. Overall, the density of GR-IR cells in the cerebellum was lower than expected based on the levels of GR mRNA detected in this region by in situ hybridization (Fig. 1). Most of the GR-immunopositive nuclei found within the prefrontal and entorhinal cortices, as well as in the cerebellar cortex showed colocalization with MAP-2 (see Fig. $5 A, B$ ), indicating a neuronal phenotype.

Within the rhesus monkey hippocampal formation, the density of GR-immunoreactive cells was low, and those positive cells detected were weakly immunoreactive (Fig. 4). Only a moderate density of weakly immunoreactive nuclei were observed in the subiculum-prosubiculum and granule cell layer of the DG (Fig.
$4 B)$. In the DG, the large nuclear profile size appeared to belong to neurons, and this was confirmed by the colocalization of GR with MAP-2 in these cells (data not shown). Weak cytoplasmic GR immunoreactivity was observed within the pyramidal cell layer of the subiculum-prosubiculum. Only scattered and moderately immunoreactive nuclei were consistently detected throughout the molecular, and less throughout the pyramidal layers of CA1-CA4 Ammon's horn hippocampal subfields in the rhesus monkey. The predominant small nuclear profile size of many of these GR-immunoreactive cells indicated that they might be glia (Fig. $4 C-E$ ), and this was confirmed by the observation that most of these GR-IR cells were also GFAP-immunopositive (Fig. 5D). Surprisingly, the MAP-2-immunopositive putative neurons within CA1-CA4 pyramidal cell layers lacked GR immunostaining (Fig. $5 C$ ). In contrast, using the same antibodies developed to recognize the human GR, the rat hippocampus showed a high density of strongly GR-IR nuclei within the granule cell layer of the DG and pyramidal cell layer of CA1 and CA2 (Fig. 6). Consistent with the apparent species difference in GR-IR in the hippocampal formation, neither the number nor intensity of GRimmunopositive cells in the macaque amygdala was as high as in 

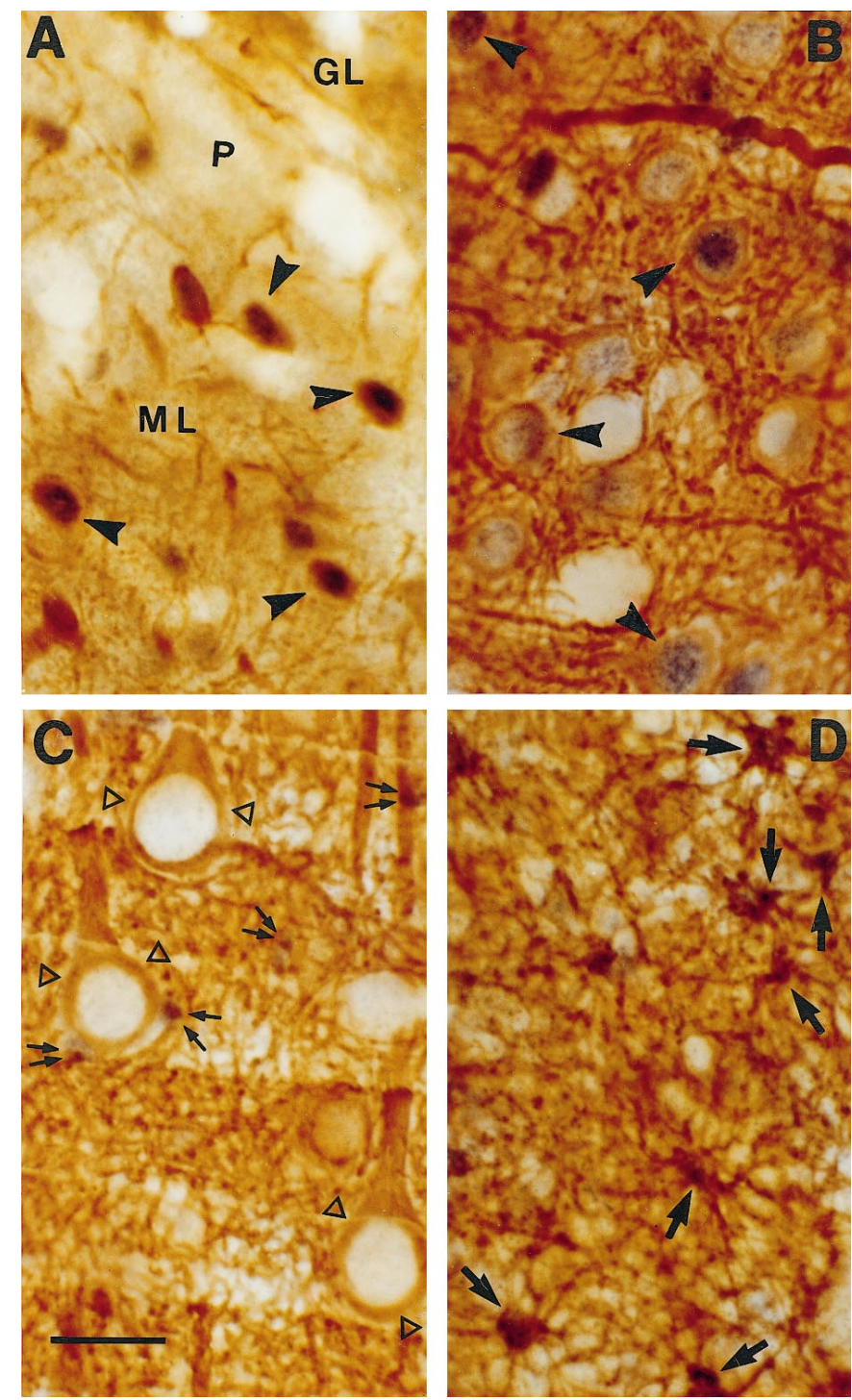

Figure 5. Light micrographs showing immunohistochemical colocalization of GR (purple) with MAP-2 $(A-C)$ or with GFAP $(D)$ (brown) in coronal sections through sampled regions of the macaque CNS. $A$, Colocalization of GR (in nucleus) and MAP-2 (in cytoplasm and dendrites) in cerebellar cortex neurons (arrowheads); B, prefrontal cortex neurons showing double staining for GR and MAP-2 (arrowheads); $C$, CA1 pyramidal neurons in the hippocampus were MAP-2-immunopositive (open triangles), but did not show GR immunoreaction (double arrows point to small GR-IR nuclei scattered among the pyramidal neurons); $D$, glial cells in CA1 pyramidal cell layer showing colocalization of GR (nucleus) and GFAP (arrows). Scale bar, $20 \mu \mathrm{m}$.

the central nucleus of the amygdala in the rat using the same human antibody (data not shown).

\section{MR in situ hybridization}

In comparison with the distribution pattern of GR mRNA, the MR mRNA hybridization signal was intense throughout the macaque hippocampal formation. Message was evident in the DG as well as in Cornu Ammonis subfields CA1-CA4, with the highest MR mRNA levels detected within the DG and CA2-CA3 (Fig. $7 A$ ). In the rat, the MR mRNA hybridization signal was also high in DG and CA subfields (Fig. $8 A$ ), although levels were lower in CA3 than in the other Ammon's horn subfields. Hybridization of adjacent sections using the MR sense cRNA probe yielded unde-
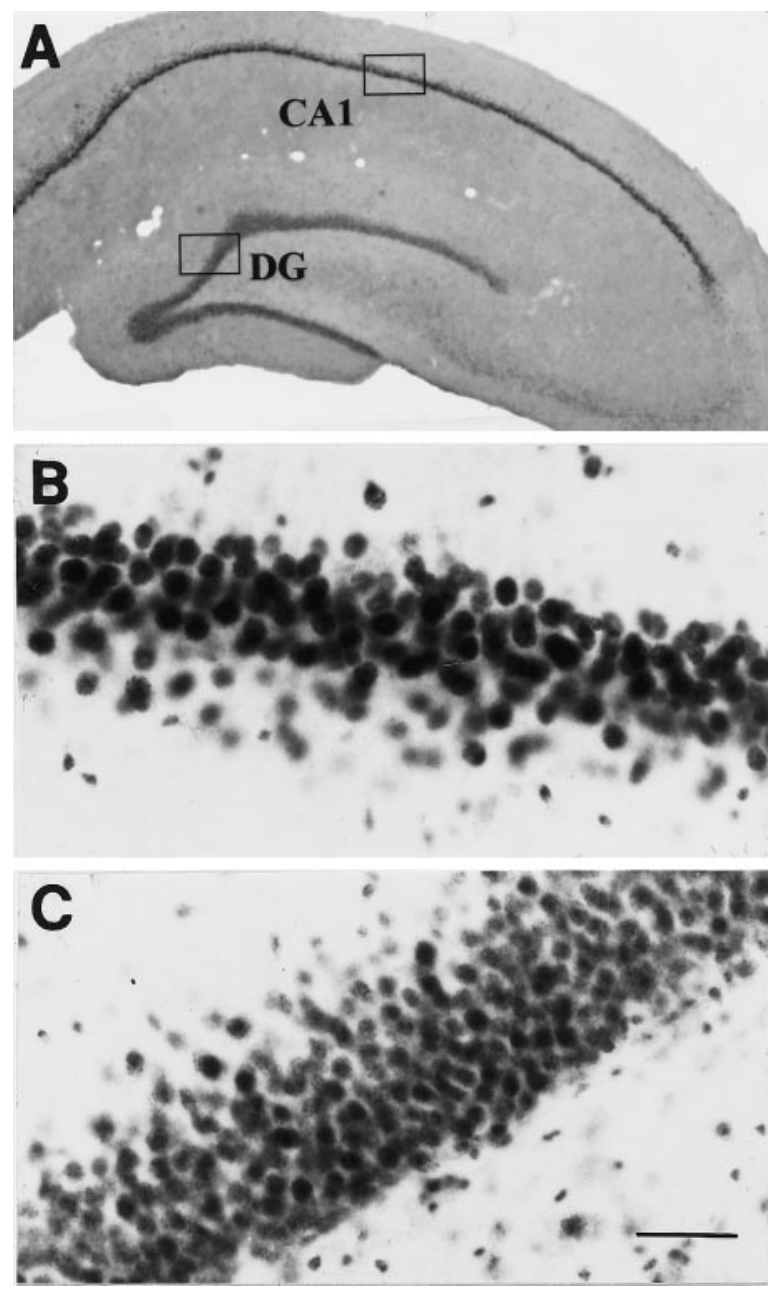

Figure 6. GR-immunoreactive cells in the rat hippocampal formation. $A$, Low magnification; high densities of strongly immunoreactive cells were found within the pyramidal cell layer of CA1 and CA2 $(B)$ and the granule cell layer of the DG $(C)$, in comparison to the scattered and moderately or weakly immunostained nuclei present in the rest of the Cornu Ammonis subfields. Note the predominant and intense nuclear immunoreactivity. Scale bar, $50 \mu \mathrm{m}$.

tectable signal in either the macaque or rat hippocampal formation (Figs. $7 B, 8 B$ ).

\section{MR immunocytochemistry}

In agreement with the data derived from in situ hybridization, a high density of intensely stained MR-immunopositive cells was evident within the hippocampal formation of the adult rhesus macaque (Fig. 9), including DG, hippocampus proper (i.e., Cornu Ammonis subfields: CA1, CA2, CA3, and CA4), subiculum, and prosubiculum. High densities of intensely MR-immunopositive nuclei were found within the granule cell layer of the DG as well as in the narrow pyramidal cell layer of CA2 and CA3. Scattered immunopositive nuclei were also evident in the stratum oriens of these two Ammon's horn subfields. In the CA1 subfield, a high density of moderately immunopositive cells was observed in the pyramidal cell layer (Fig. 9C). In addition to the predominant localization of immunoreactivity in the nucleus, weak cytoplasmic and dendritic immunostaining was also detected in CA1 (Fig. 9C) and CA4 pyramidal neurons (Fig. 9E), although the density of MR-IR cells was lower in this subfield, and the staining intensity was weaker than in the rest of the hippocampus proper. 

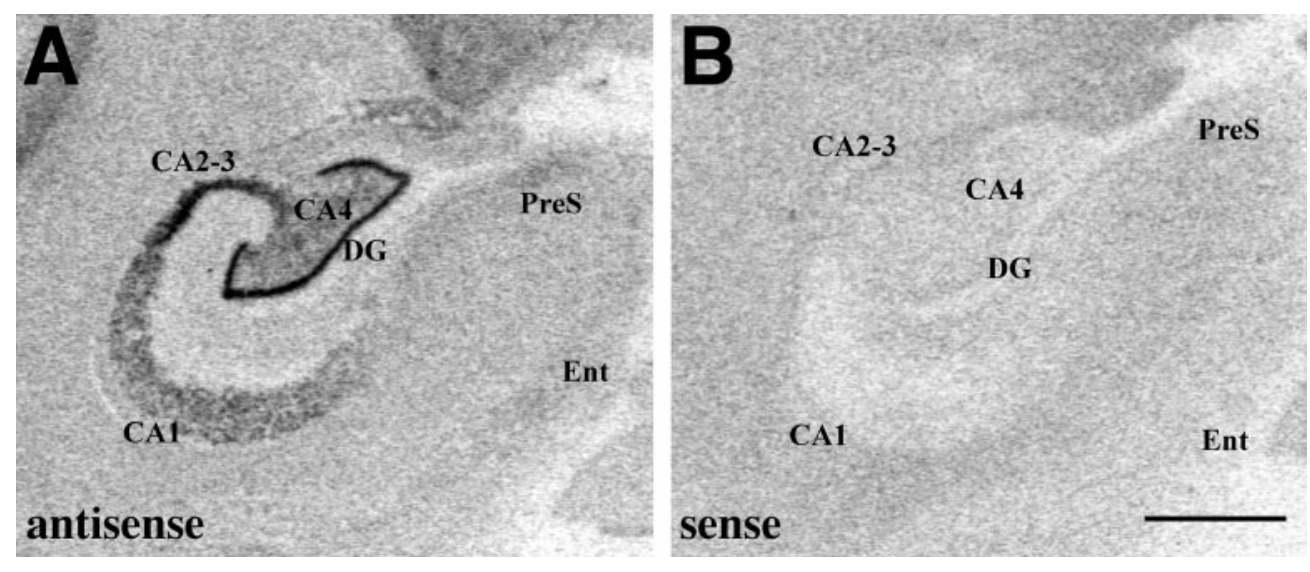

Figure 7. A, Representative autoradiogram showing MR mRNA in situ hybridization signal within the rhesus monkey hippocampal formation. Note the high levels of MR mRNA detected within the DG and Ammon's horn subfields, specifically within CA2-CA3 subfields. $B$, Hybridization signal detected when using the sense cRNA radiolabeled probe in adjacent sections. Scale bar, $1.5 \mathrm{~mm}$.

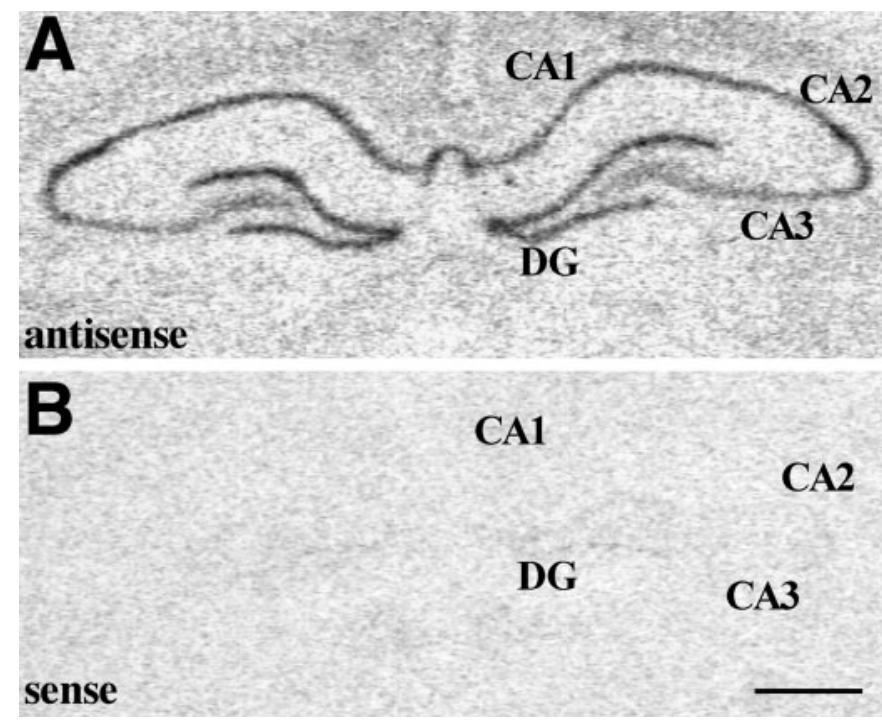

Figure 8. A, MR mRNA in situ hybridization signal within the rat hippocampal formation. Note the high levels of MR mRNA detected within the DG and Ammon's horn subfields; $B$, hybridization signal detected when using the sense cRNA radiolabeled probe in adjacent sections. Scale bar, $1 \mathrm{~mm}$.

The large nuclear profile of these cells suggested that they were of neuronal phenotype. Similar to the macaque, in the rat (Fig. 10) a high density of darkly stained MR-immunopositive large nuclei was present in the DG and Ammon's horn of the hippocampus.

\section{DISCUSSION}

The patterns of the GR mRNA and protein distribution observed in this study suggest that the GR is only weakly expressed in the rhesus hippocampal formation in contrast to the high levels of expression detected in pituitary, cerebellar cortex, hypothalamic PVN and neocortex. The high levels of both MR-like immunoreactivity and mRNA detected in the primate hippocampal formation may provide an alternative target for glucocorticoid effects.

The distribution and levels of GR and MR specific immunostaining paralleled the mRNA hybridization signal obtained with the GR and MR cRNA probes, respectively. An exception was the cerebellar cortex, where we observed very high levels of GR mRNA, but only a moderate density of GR-immunoreactive cells. This mismatch, previously reported in rat (Morimoto et al., 1996), may reflect posttranslational modifications or differences in protein stability among areas. The fact that both the MR mRNA hybridization and immunohistochemical signals were very intense in primate hippocampal sections adjacent to those used for the GR studies, as well as the high levels of GR mRNA and protein in the rat hippocampal sections, argue against a generalized problem of penetrability of the GR probe or antibodies in the primate hippocampus caused by fixation/digestion conditions during the experiments or packing density of the cells in comparison to other regions. Although the GR cRNA probe used hybridizes with the $\alpha$, but not the $\beta$, GR mRNA, the use of GR antibodies that react with both the $\alpha$ and $\beta$ GR isoforms in our immunohistochemical studies indicate that the levels of both GR isoforms are low in the rhesus hippocampus.

The pattern of GR and MR distribution in the rat was consistent with previous reports (Table 2) and is consistent with results from receptor-binding studies (McEwen et al., 1986; Jacobson and Sapolsky, 1991). Interestingly, CA1-CA2 pyramidal cells and DG granule cells coexpress GR and MR in the rat, suggesting integration of the activation of both receptors depending on the circulating levels of corticosterone (de Kloet et al., 1994). In contrast to the rat, the monkey hippocampus contained low levels of GR mRNA and protein that were mainly detected within the DG granule cell layer and the subiculum-prosubiculum pyramidal cell layer. The colocalization of GR with GFAP in the molecular layers of different subfields suggests that these small GR-IR nuclei belong to glial cells. In contrast to GR, MR mRNA and protein levels were high in the rhesus hippocampal formation, specifically in the DG granule cell layer and CA1-CA3 pyramidal cell layers, in agreement with previous reports of MR mRNA in human (Seckl et al., 1991) and nonhuman hippocampus (Johnson et al., 1996).

Detectable levels of GR mRNA have been reported in the hippocampal formation of human (Seckl et al., 1991, 1993; Tohgi et al., 1995; Wetzel et al., 1995; Lopez et al., 1998) and nonhuman primates (Johnson et al., 1996) by means of in situ hybridization or RT-PCR (De Rijk et al., 1998). In agreement with our results, GR mRNA was detected in DG, although some studies also reported hybridization within the Ammon's horn, particularly in CA3. Unfortunately, these studies do not report GR mRNA and protein levels of expression in other CNS regions, making it difficult to compare the relative abundance of GR in the hippocampus. Separate immunohistochemical observations support our conclusion that the macaque hippocampal formation-in particular the hippocampus proper-may not be the major site of GR expression (Öngür and Price, 1997; Leverenz et al., 1999a). While the human hippocampus may be different from that of the 
Figure 9. Immunohistochemical localization of MR in the rhesus monkey hippocampal formation. $A$, Low magnification field of view; $B$, high density of moderately MR-IR nuclei (arrows) within the DG granule cell layer; $C$, high density of MR-IR cells, moderately immunostained, in the CA1 subfield, where weak cytoplasmic (star) and dendritic (open triangles) immunostaining was detected in addition to the predominant nuclear immunoreactivity (arrows); E, this same pattern was observed in the CA4 pyramidal cell layer, although less density of MR-IR cells was detected; $D$, intensely MR-IR cells in the pyramidal cell layer of CA2 and CA3. Scale bar, $50 \mu \mathrm{m}$.


monkey, some human studies also contradict predictions about corticosteroid receptor regulation based on the rodent literature. For example, the upregulation (Wetzel et al., 1995), or lack of change (Seckl et al., 1993), of hippocampal GR mRNA in hypercortisolemic Alzheimer's disease patients is opposite to the predicted decreased levels expected with high plasma corticosterone in rats.

Although the distribution of GRs and MRs has not been fully characterized in the primate brain, there have been some quantitative analyses of receptor binding. Given the caveat that in most studies the true binding values may be masked because of receptor occupancy by endogenous hormones (Tsuboi et al., 1979; Sarrieau et al., 1986; Brooke et al., 1994a), the reported number of available (unoccupied) GR binding sites in the primate hippocampus was lower than in the neocortex, cerebellum, or hypothalamus (Brooke et al., 1994b). It is noteworthy that in some of these cases dissection of the hippocampal formation included the entorhinal cortex, an area showing high levels of GR in our study. To avoid the confound of endogenous hormones, other studies have measured binding of $\left[{ }^{3} \mathrm{H}\right]$-dexamethasone or $\left[{ }^{3} \mathrm{H}\right]$-cortisol in adrenalectomized or metyrapone-treated primates (Gerlach et al., 1976; Sapolsky and Meaney, 1988). Although the reported binding was high in Cornu Ammonis and hippocampal DG, these ligands cannot distinguish between the MR and GR in the primate. Apart from the higher affinity of cortisol for the MR, dexamethasone has high affinity for both primate corticosteroid receptor types (Rupprecht et al., 1993), an important species difference from rat receptors (Krozowski and Funder, 1983; Sutanto and de Kloet, 1987). Thus, the high levels of MR found within the macaque Ammon's horn and DG could be at least partially responsible for the previously reported binding of glucocorticoids in the primate hippocampus.

There is evidence that stress-induced glucocorticoid elevations participate along with excitatory amino acids in mediating alterations in hippocampal morphology, including dendritic atrophy, suppression of ongoing neurogenesis (Cameron et al., 1995; McEwen, 1997), and even neuronal loss (Sapolsky et al., 1985). The thesis of hippocampal involvement in the neurodegenerative/ cognitive effects of corticosteroids has been supported by the high density of GRs in the rodent hippocampus (McEwen et al., 1986) thought to be a principal neural target tissue of GCs (Sapolsky and Pulsinelli, 1985; McEwen et al., 1992). GRs have been impli- 


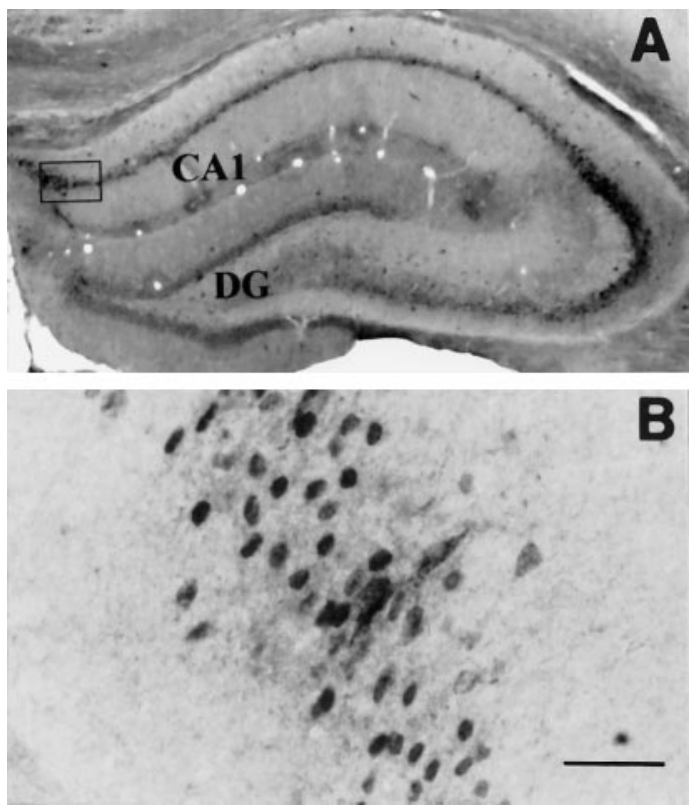

Figure 10. MR immunohistochemical localization in the rat hippocampal formation. $A$, Low magnification field of view; $B$, high density of darkly immunostained MR-IR nuclei in the rat CA1 of the hippocampus, as a representative example. Scale bar, $50 \mu \mathrm{m}$.

cated in the GC-mediated degeneration of pyramidal cells in the Ammon's horn after chronic stress in rats (Kerr et al., 1991; Watanabe et al., 1992) or psychosocial conflict in tree shrews (Magariños et al., 1997). The alterations reported, including neuronal loss, dendritic atrophy, and alterations in synaptic struc- ture, are similar to the effects of chronic administration of high levels of corticosterone (Woolley et al., 1990). Paradoxically, the damage is found primarily among the CA3 pyramidal neurons, (Woolley et al., 1990; Magariños et al., 1997), which contain considerably lower levels of GRs than other Ammon's horn subfields or the DG in the rat. In spite of this anatomical mismatch, it is generally accepted that GCs act directly on rat hippocampal neurons to compromise their ability to survive different metabolic insults (Sapolsky et al., 1988; Lawrence and Sapolsky, 1994), including endogenously released excitatory amino acids (Sapolsky and Pulsinelli, 1985; Armanini et al., 1990; Virgin et al., 1991; Moghaddam et al., 1994), at least partially through GC-induced inhibition of glucose uptake by these neurons (Kadekaro et al., 1988).

Cellular damage has also been reported in CA2/CA3 pyramidal neurons of vervet monkeys exposed to fatal social stress (Uno et al., 1989) or cortisol (Sapolsky et al., 1990). An inverse correlation between plasma cortisol concentrations and hippocampal formation volume has been detected in patients with spontaneous Cushing's syndrome (Starkman et al., 1999), recurrent depressive disorder (Sheline et al., 1996), or post-traumatic stress disorder (PTSD) (Bremner et al., 1995). However, not all studies have consistently found negative effects of glucocorticoids on the primate hippocampus. Chronic high-dose GC administration did not result in neuronal loss or in density or volume changes of any hippocampal subfield, including CA2/3 (Leverenz et al., 1999b), areas considered most vulnerable to GC neurotoxic effects (Landfield et al., 1981; Sapolsky et al., 1985). Similarly, no "major morphological changes or signs of neuronal cell death" were found in hippocampi of corticosteroid-treated or depressed patients (Müller et al., 1998; D. F. Swaab, personal communication),

\section{Table 2. Relative densities of GR-/MR-immunoreactive and GR/MR mRNA-containing cells in some regions of the rat CNS}

\begin{tabular}{|c|c|c|c|c|}
\hline \multirow[b]{2}{*}{ Region } & \multicolumn{2}{|l|}{$\mathrm{GR}^{a, b}$} & \multicolumn{2}{|l|}{$\mathrm{MR}^{c}$} \\
\hline & GR-IR cells & GR mRNA & MR-IR cells & MR mRNA \\
\hline \multicolumn{5}{|l|}{ Hippocampal formation } \\
\hline $\mathrm{DG}, \mathrm{CA} 1$ and 2 & +++ & ++++ & +++ & +++ \\
\hline CA 3 and 4 & $+/++$ & + & +++ & +++ \\
\hline Amygdaloid nuclei (CEA, MEA) & $++/+++$ & +++ & ++ & $+/++$ \\
\hline Neocortex & ++ & ++ & ++ & ++ \\
\hline \multicolumn{5}{|l|}{ Septal region } \\
\hline Lateral septal nucleus & ++ & $+/++$ & +++ & +++ \\
\hline Medial septal nucleus & $-1+$ & + & ++ & ++ \\
\hline BNST, caudate putamen & $++/+++$ & ++ & $++/+++$ & $+/++$ \\
\hline \multicolumn{5}{|l|}{ Hypothalamus } \\
\hline PVN & +++ & +++ & + & - \\
\hline SON & $-/+$ & $++/+++$ & + & - \\
\hline VMH, arcuate n. & $++/+++$ & +++ & ++ & $-/+$ \\
\hline Thalamic nuclei & ++ & $++/+++$ & $++/+++$ & ++ \\
\hline \multicolumn{5}{|l|}{ Brainstem } \\
\hline Locus coeruleus & +++ & +++ & - & - \\
\hline n. solitary tract, ambiguus, trigeminal, red & $+/++$ & ++ & ++ & +++ \\
\hline Spinal cord & ++ & + & ++ & +++ \\
\hline Cerebellar ctx (Purkinje and granule cells) & $++/+++$ & $++/+++$ & ++ & $+/++$ \\
\hline Circumventricular organs (subfornical organ) & $-1+$ & + & +++ & - \\
\hline White and pia matter, choroid plexus & + (glia) & + & $-/+$ & - \\
\hline
\end{tabular}

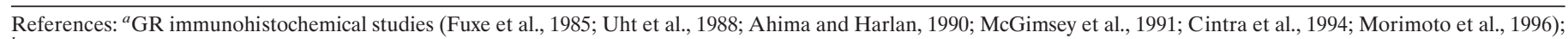

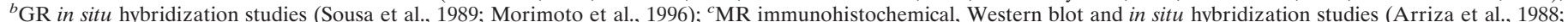

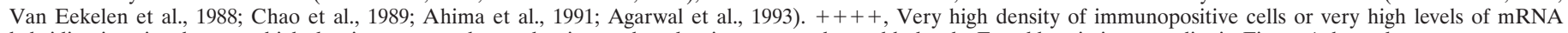
hybridization signal; +++ , high density; ++, moderate density; +, low density; - , non-detectable levels. For abbreviations, see list in Figure 1 , legend. 
whereas changes in the hypothalami were reported (Erkut et al., 1998). Accordingly, despite elevated baseline cortisol in children with PTSD (De Bellis et al., 1999a), no decreases in hippocampal volume were observed by means of MRI (De Bellis et al., 1999b). A low density of GR in the primate hippocampal formation could partially explain these results and introduces the possibility that glucocorticoids effects are different in the primate and rodent hippocampus. Although the (low) GR levels detected in the DG could be mediating GC effects on neurogenesis, GC effects, if any, on Ammon's horn pyramidal neurons are probably indirect either through the heavy excitatory afferent input they receive from the DG granule neurons, or through their interaction with GRexpressing glial cells. The paucity of GRs in the primate CA1-4 pyramidal neurons suggests that the mechanism of adrenal steroid actions in the hippocampus proper needs to be re-evaluated.

Interestingly, stress and GCs also increase extracellular glutamate accumulation in neocortical areas (Lowy et al., 1993; Moghaddam, 1993; Moghaddam et al., 1994; Stein-Behrens et al., 1994) where signs of neuronal degeneration have been detected in addition to the damage reported in the primate hippocampus (Uno et al., 1989, 1990). The high density of GR in the neocortex, hypothalamus, and cerebellum suggests that, in primates, these areas might also serve as targets for the neurodegenerative actions of GCs, mediating the cognitive, behavioral, and endocrine impairments observed after chronic stress or prolonged exposure to GCs.

In summary, very low levels of GR mRNA and protein were observed in the primate hippocampal formation, particularly in the Ammon's horn subfields, where high levels of MR mRNA and protein were detected. This pattern is in stark contrast to that in the rat. Both MRs and GRs interact to regulate HPA axis activity (Arriza et al., 1988; Spencer et al., 1998). The hypothesis that the GR:MR ratio reflects regional susceptibility to stress or GCs (de Kloet et al., 1993) and that MRs may serve a neuroprotective role in response to excitotoxic challenge (McCullers and Herman, 1998) reinforces the need to explore the potential role of the high density of MRs present in the primate hippocampus.

\section{REFERENCES}

Agarwal MK, Mirshahi F, Mirshahi M, Rostene W (1993) Immunochemical detection of the mineralocorticoid receptor in rat brain. Neuroendocrinology 58:575-580.

Ahima RS, Harlan RE (1990) Charting of type II glucocorticoid receptor-like immunoreactivity in the rat central nervous system. Neuroscience 39:579-604.

Ahima R, Krozowski Z, Harlan R (1991) Type I corticosteroid receptorlike immunoreactivity in the rat CNS: distribution and regulation by corticosteroids. J Comp Neurol 313:522-538.

Alnemri ES, Maksymowych AB, Robertson NM, Litwack G (1991) Overexpression and characterization of the human mineralocorticoid receptor. J Biol Chem 266:18072-18081.

Armanini MP, Hutchins C, Stein BA, Sapolsky RM (1990) Glucocorticoid endangerment of hippocampal neurons is NMDA-receptor dependent. Brain Res 532:7-12.

Arriza JL, Weinberger C, Cerelli G, Glaser TM, Handelin BL, Housman DE, Evans RM (1987) Cloning of human mineralocorticoid receptor complementary DNA: structural and functional kinship with the glucocorticoid receptor. Science 237:268-275.

Arriza JL, Simerly RB, Swanson LW, Evans RM (1988) The neuronal mineralocorticoid receptor as a mediator of glucocorticoid response. Neuron 1:887-900.

Bremner JD (1999) Does stress damage the brain? Biol Psychiatry 45:797-805.

Bremner JD, Randall P, Scott TM, Bronen RA, Seibyl JP, Southwick SM, Delaney RC, McCarthy G, Charney DS, Innis RB (1995) MRI-based measurement of hippocampal volume in patients with combat-related posttraumatic stress disorder. Am J Psychiatry 152:973-981.
Brooke SM, de Haas-Johnson AM, Kaplan JR, Manuck SB, Sapolsky RM (1994a) Dexamethasone resistance among nonhuman primates associated with a selective decrease of glucocorticoid receptors in the hippocampus and a history of social instability. Neuroendocrinology 60:134-140.

Brooke SM, de Haas-Johnson AM, Kaplan JR, Sapolsky RM (1994b) Characterization of mineralocorticoid and glucocorticoid receptors in primate brain. Brain Res 637:303-307.

Cameron HA, McEwen BS, Gould E (1995) Regulation of adult neurogenesis by excitatory input and NMDA receptor activation in the dentate gyrus. J Neurosci 15:4687-4692.

Chao HM, Choo PH, McEwen BS (1989) Glucocorticoid and mineralocorticoid receptor mRNA expression in rat brain. Neuroendocrinology 50:365-371.

Cintra A, Zoli M, Rosen L, Agnati LF, Okret S, Wikstrom AC, Gustaffsson JA, Fuxe K (1994) Mapping and computer assisted morphometry and microdensitometry of glucocorticoid receptor immunoreactive neurons and glial cells in the rat central nervous system. Neuroscience 62:843-897.

Coirini H, Magariños AM, De Nicola AF, Rainbow TC, McEwen BS (1985) Further studies of brain aldosterone binding sites employing new mineralocorticoid and glucocorticoid receptor markers in vitro. Brain Res 361:212-216.

De Bellis MD, Baum AS, Birmaher B, Keshavan MS, Eccard CH, Boring AM, Jenkins FJ, Ryan ND (1999a) AE Bennett research award. Developmental traumatology. Part I: Biological stress systems. Biol Psychiatry 45:1259-1270.

De Bellis MD, Keshavan MS, Clark DB, Casey BJ, Giedd JN, Boring AM, Frustaci K, Ryan ND (1999b) AE Bennett research award. Developmental traumatology. Part II: Brain development. Biol Psychiatry 45:1271-1284.

de Kloet ER, Ratka A, Reul JM, Sutanto W, Van Eekelen JA (1987) Corticosteroid receptor types in brain: regulation and putative function. Ann NY Acad Sci 512:351-361.

de Kloet ER, Oitzl MS, Joels M (1993) Functional implications of brain corticosteroid receptor diversity. Cell Mol Neurobiol 13:433-455.

de Kloet ER, Rots NY, van den Berg DT, Oitzl MS (1994) Brain mineralocorticoid receptor function. Ann NY Acad Sci 746:8-20.

De Rijk RH, Stam FJ, Oitzl MS, Swaab DF, Vreugdenhil E, Datson N, Roovers E, de Kloet ER, Lucassen PJ (1998) Identification of the glucocorticoid receptor $\beta$-form in the human hippocampus. Soc Neurosci Abstr 24:1380.

Erkut ZA, Pool C, Swaab DF (1998) Glucocorticoids suppress corticotropin-releasing hormone and vasopressin expression in human hypothalamic neurons. J Clin Endocrinol Metab 83:2066-2073.

Fuxe K, Wikstrom AC, Okret S, Agnati LF, Harfstrand A, Yu ZY, Granholm L, Zoli M, Vale W, Gustafsson JA (1985) Mapping of glucocorticoid receptor immunoreactive neurons in the rat tel- and diencephalon using a monoclonal antibody against rat liver glucocorticoid receptor. Endocrinology 117:1803-1812.

Gerlach JL, McEwen BS, Pfaff DW, Moskovitz S, Ferin M, Carmel PW, Zimmerman EA (1976) Cells in regions of rhesus monkey brain and pituitary retain radioactive estradiol, corticosterone and cortisol differentially. Brain Res 103:603-612.

Hollenberg SM, Weinberger C, Ong ES, Cerelli G, Oro A, Lebo R, Thompson EB, Rosenfeld MG, Evans RM (1985) Primary structure and expression of a functional human glucocorticoid receptor cDNA. Nature 318:635-641.

Jacobson L, Sapolsky R (1991) The role of the hippocampus in feedback regulation of the hypothalamic-pituitary-adrenocortical axis. Endocr Rev 12:118-134.

Johnson EO, Brady L, Gold PW, Chrousos GP (1996) Distribution of hippocampal mineralocorticoid and glucocorticoid receptor mRNA in a glucocorticoid resistant nonhuman primate. Steroids 61:69-73.

Kadekaro M, Ito M, Gross PM (1988) Local cerebral glucose utilization is increased in acutely adrenalectomized rats. Neuroendocrinology 47:329-334.

Kerr DS, Campbell LW, Applegate MD, Brodish A, Landfield PW (1991) Chronic stress-induced acceleration of electrophysiologic and morphometric biomarkers of hippocampal aging. J Neurosci 11:1316-1324.

Krozowski ZS, Funder JW (1983) Renal mineralocorticoid receptors and hippocampal corticosterone-binding species have identical intrinsic steroid specificity. Proc Natl Acad Sci USA 80:6056-6060. 
Landfield PW, Baskin RK, Pitler TA (1981) Brain aging correlates: retardation by hormonal-pharmacological treatments. Science 214:581-584

Lawrence MS, Sapolsky RM (1994) Glucocorticoids accelerate ATP loss following metabolic insults in cultured hippocampal neurons. Brain Res 646:303-306.

Leverenz JB, Wilkinson CW, Raskind MA, Peskind ER (1999a) Immunohistochemical localization of glucocorticoid and mineralocorticoid receptors in the primate hippocampus and amygdala. Soc Neurosci Abstr 25:708.

Leverenz JB, Wilkinson CW, Wamble M, Corbin S, Grabber JE, Raskind MA, Peskind ER (1999b) Effect of chronic high-dose exogenous cortisol on hippocampal neuronal number in aged nonhuman primates. J Neurosci 19:2356-2361.

Lopez JF, Chalmers DT, Little KY, Watson SJ (1998) A.E. Bennett Research Award. Regulation of serotonin1A, glucocorticoid, and mineralocorticoid receptor in rat and human hippocampus: implications for the neurobiology of depression. Biol Psychiatry 43:547-573.

Lowy MT, Gault L, Yamamoto BK (1993) Adrenalectomy attenuates stress-induced elevations in extracellular glutamate concentrations in the hippocampus. J Neurochem 61:1957-1960.

Luttge WG, Rupp ME (1989) Differential up- and down-regulation of type I and type II receptors for adrenocorticosteroid hormones in mouse brain. Steroids 53:59-76.

Magariños AM, Verdugo JM, McEwen BS (1997) Chronic stress alters synaptic terminal structure in hippocampus. Proc Natl Acad Sci USA 94:14002-14008.

Martin RF, Bowden DM (1997) Template atlas of the primate brain. Seattle Primate Information Center: University of Washington, Seattle.

McCullers DL, Herman JP (1998) Blockade of mineralocorticoid receptors increases hippocampal cell death following kainic acid treatment. Soc Neurosci Abstr 24:1380.

McEwen BS (1997) Possible mechanisms for atrophy of the human hippocampus. Mol Psychiatry 2:255-262.

McEwen BS, de Kloet ER, Rostene W (1986) Adrenal steroid receptors and actions in the nervous system. Physiol Rev 66:1121-1188.

McEwen BS, Gould EA, Sakai RR (1992) The vulnerability of the hippocampus to protective and destructive effects of glucocorticoids in relation to stress. Br J Psychiatry [Suppl] 15:18-23.

McGimsey WC, Cidlowski JA, Stumpf WE, Sar M (1991) Immunocytochemical localization of the glucocorticoid receptor in rat brain, pituitary, liver, and thymus with two new polyclonal antipeptide antibodies. Endocrinology 129:3064-3072.

Moghaddam B (1993) Stress preferentially increases extraneuronal levels of excitatory amino acids in the prefrontal cortex: comparison to hippocampus and basal ganglia. J Neurochem 60:1650-1657.

Moghaddam B, Bolinao ML, Stein-Behrens B, Sapolsky R (1994) Glucocorticoids mediate the stress-induced extracellular accumulation of glutamate. Brain Res 655:251-254.

Morimoto M, Morita N, Ozawa H, Yokoyama K, Kawata M (1996) Distribution of glucocorticoid receptor immunoreactivity and mRNA in the rat brain: an immunohistochemical and in situ hybridization study. Neurosci Res 26:235-269.

Müller MB, Lucassen PJ, Yassouridis A, Hoogendijk WJG, Holsboer F, Swaab DF (1998) The human hippocampus in major depression or following administration of glucocorticoids: no evidence for major structural alterations. Soc Neurosci Abstr 24:990.

Öngür D, Price JL. (1997) Distribution of glucocorticoid receptors in the macaque central nervous system. Soc Neurosci Abstr 23:1494.

Paxinos G, Huang X-F, Toga AW (2000) The rhesus monkey brain in stereotaxic coordinates. San Diego, CA: Academic.

Reul JM, de Kloet ER (1985) Two receptor systems for corticosterone in rat brain: microdistribution and differential occupation. Endocrinology 117:2505-2511.

Reul JM, de Kloet ER, van Sluijs FJ, Rijnberk A, Rothuizen J (1990) Binding characteristics of mineralocorticoid and glucocorticoid receptors in dog brain and pituitary. Endocrinology 127:907-915.

Rosene DL, Van Hoesen GW (1987) The hippocampal formation of the primate brain. A review of some comparative aspects of cytoarchitecture and connections. In: Cerebral cortex. (Jones EG, Peters A, eds), pp 345-456. New York: Plenum.

Rupprecht R, Reul JM, van Steensel B, Spengler D, Soder M, Berning B, Holsboer F, Damm K (1993) Pharmacological and functional charac- terization of human mineralocorticoid and glucocorticoid receptor ligands. Eur J Pharmacol 247:145-154.

Sánchez MM, Young LJ, Plotsky PM, Insel TR (1999) Autoradiographic and in situ hybridization localization of corticotropin-releasing factor 1 and 2 receptors in nonhuman primate brain. J Comp Neurol 408:365-377.

Sapolsky RM, Meaney MJ (1988) Postmortem decay in glucocorticoid binding in human and primate brain. Brain Res 448:182-185.

Sapolsky RM, Pulsinelli WA (1985) Glucocorticoids potentiate ischemic injury to neurons: therapeutic implications. Science 229:1397-1400.

Sapolsky RM, Krey LC, McEwen BS (1985) Prolonged glucocorticoid exposure reduces hippocampal neuron number: implications for aging. J Neurosci 5:1222-1227.

Sapolsky RM, Krey LC, McEwen BS (1986) The neuroendocrinology of stress and aging: the glucocorticoid cascade hypothesis. Endocr Rev 7:284-301.

Sapolsky RM, Packan DR, Vale WW (1988) Glucocorticoid toxicity in the hippocampus: in vitro demonstration. Brain Res 453:367-371.

Sapolsky RM, Uno H, Rebert CS, Finch CE (1990) Hippocampal damage associated with prolonged glucocorticoid exposure in primates. J Neurosci 10:2897-2902.

Sarrieau A, Dussaillant M, Agid F, Philibert D, Agid Y, Rostene W (1986) Autoradiographic localization of glucocorticosteroid and progesterone binding sites in the human post-mortem brain. J Steroid Biochem 25:717-721.

Seckl JR, Dickson KL, Yates C, Fink G (1991) Distribution of glucocorticoid and mineralocorticoid receptor messenger RNA expression in human postmortem hippocampus. Brain Res 561:332-337.

Seckl JR, French KL, O’Donnell D, Meaney MJ, Nair NP, Yates CM, Fink. (1993) Glucocorticoid receptor gene expression is unaltered in hippocampal neurons in Alzheimer's disease. Brain Res Mol Brain Res 18:239-245.

Sheline YI, Wang PW, Gado MH, Csernansky JG, Vannier MW (1996) Hippocampal atrophy in recurrent major depression. Proc Natl Acad Sci USA 93:3908-3913.

Snider RS, Lee JC (1961) A stereotaxic atlas of the monkey brain (Macaca mulatta). Chicago: The University of Chicago.

Sousa RJ, Tannery NH, Lafer EM (1989) In situ hybridization mapping of glucocorticoid receptor messenger ribonucleic acid in rat brain. Mol Endocrinol 3:481-494.

Spencer RL, Kim PJ, Kalman BA, Cole MA (1998) Evidence for mineralocorticoid receptor facilitation of glucocorticoid receptordependent regulation of hypothalamic-pituitary-adrenal axis activity. Endocrinology 139:2718-2726.

Starkman MN, Giordani B, Gebarski SS, Berent S, Schork MA, Schteingart DE (1999) Decrease in cortisol reverses human hippocampal atrophy following treatment of Cushing's disease. Biol Psychiatry 46:1595-1602.

Stein-Behrens BA, Lin WJ, Sapolsky RM (1994) Physiological elevations of glucocorticoids potentiate glutamate accumulation in the hippocampus. J Neurochem 63:596-602.

Sutanto W, de Kloet ER (1987) Species-specificity of corticosteroid receptors in hamster and rat brains. Endocrinology 121:1405-1411.

Tohgi H, Utsugisawa K, Yamagata M, Yoshimura M (1995) Effects of age on messenger RNA expression of glucocorticoid, thyroid hormone, androgen, and estrogen receptors in postmortem human hippocampus. Brain Res 700:245-253.

Tsuboi S, Kawashima R, Tomioka O, Nakata M, Sakamoto N, Fujita T (1979) Glucocorticoid binding proteins of human brain cytosol. Brain Res 179:181-185.

Uht RM, McKelvy JF, Harrison RW, Bohn MC (1988) Demonstration of glucocorticoid receptor-like immunoreactivity in glucocorticoidsensitive vasopressin and corticotropin-releasing factor neurons in the hypothalamic paraventricular nucleus. J Neurosci Res 19:405-411.

Uno H, Tarara R, Else JG, Suleman MA, Sapolsky RM (1989) Hippocampal damage associated with prolonged and fatal stress in primates. J Neurosci 9:1705-1711.

Uno H, Lohmiller L, Thieme C, Kemnitz JW, Engle MJ, Roecker EB, Farrell PM (1990) Brain damage induced by prenatal exposure to dexamethasone in fetal rhesus macaques. I. Hippocampus. Brain Res Dev Brain Res 53:157-167.

Van Eekelen JA, Jiang W, de Kloet ER, Bohn MC (1988) Distribution of the mineralocorticoid and the glucocorticoid receptor mRNAs in the rat hippocampus. J Neurosci Res 21:88-94. 
Veldhuis HD, Van Koppen C, Van Ittersum M, de Kloet ER (1982) Specificity of the adrenal steroid receptor system in rat hippocampus. Endocrinology 110:2044-2051.

Virgin CEJ, Ha TP, Packan DR, Tombaugh GC, Yang SH, Horner HC, Sapolsky RM (1991) Glucocorticoids inhibit glucose transport and glutamate uptake in hippocampal astrocytes: implications for glucocorticoid neurotoxicity. J Neurochem 57:1422-1428.

Watanabe Y, Gould E, McEwen BS (1992) Stress induces atrophy of apical dendrites of hippocampal CA3 pyramidal neurons. Brain Res 588:341-345.

Wetzel DM, Bohn MC, Kazee AM, Hamill RW (1995) Glucocorticoid receptor mRNA in Alzheimer's diseased hippocampus. Brain Res 679:72-81.
Woolley CS, Gould E, McEwen BS (1990) Exposure to excess glucocorticoids alters dendritic morphology of adult hippocampal pyramidal neurons. Brain Res 531:225-231.

Young LJ, Winslow JT, Nilsen R, Insel TR (1997) Species differences in V1a receptor gene expression in monogamous and nonmonogamous voles: behavioral consequences. Behav Neurosci 111:599-605.

Yu ZY, Wrange O, Boethius J, Gustafsson JA, Granholm L (1981) A qualitative comparison of the glucocorticoid receptor in cytosol from human brain and rat brain. Brain Res 223:325-333.

Zennaro MC, Keightley MC, Kotelevtsev Y, Conway GS, Soubrier F, Fuller PJ (1995) Human mineralocorticoid receptor genomic structure and identification of expressed isoforms. J Biol Chem 270:2101621020. 